\title{
Microfinance banking and economic growth of Nigeria.
}

\author{
Wachukwu IP*, Onyema JI, Amadi SN \\ Rivers State University, Nkpolu-Oroworukwo, Port Harcourt, Nigeria
}

\begin{abstract}
The study seeks to examine the impact of microfinance bank on economic growth of Nigeria. The research estimated the specified models using the Cochran-Orcutt regression model applied on time series annual data from the central bank of Nigeria statistical bulletin and annual reports 2017 edition and world bank national account data. The study employed both descriptive and inferential statistic data in analyzing the time series data. The results garnered from the data analysis indicated among other things that; microfinance bank credit growth and investment growth were significantly but negatively related to the real gross domestic product. the microfinance bank deposit growth and asset growth were positively and significantly related to real gross domestic product. From the granger causality test, it was found that there is a bidirectional causality between real gross domestic product and microfinance bank credit growth and real gross domestic product and microfinance bank asset growth. We therefore recommend that the Central Bank of Nigeria, which plays a supervisory function over microfinance Banks should put strict measures in place to ensure that loans that are granted are used for purely economic reasons, so it can impact positively on the economy.
\end{abstract}

Keywords: Microfinance investment growth, Microfinance bank deposit growth, Microfinance asset growth, Economic growth.

Accepted on November 15, 2018

\section{Introduction}

According to Hulme and Mosley [1], the proposition that capital investment and other financial services constitute key determinants of economic growth and income improvement continues to drive most development efforts including microfinance. Hulme and Mosley [2] cited many researches that indicate a strong and positive correlation between growth and the share investment in Gross Domestic Product. It is precisely this idea that drives microfinance. It is assured that, like the positive relation between financial investment and economic growth, financial investment in the poor through microfinance service will lead to increased income of the poor and ultimately result in poverty reduction [2].

Providing access to financial services for the low-income earners in Nigeria has ever remained a daunting challenge to the manager and policy makers of the nation's economy.

Robust economic growth and development cannot be attained without formulating a well thought out programme of reducing poverty through empowering the rural poor by increasing their access to credit [3].

The CBN justified its licensing of micro finance banks with the lack of institutional capacity and weak capital base of existing community banks, the existence of huge unserved market and the need for improving savings opportunity [4]. On the issue and justification of microfinance banks, the CBN pointed out further that only $36 \%$ of Nigerian adult had access to financial services and most of those that were financially excluded are without access to financial services dwell in the rural areas. EFINA [5] documented that $46 \%$ of adult population of Nigeria were financially excluded, $17 \%$ of the nation's population do not have access to or use any bank or other financial service products but have access to informal service such as co-operatives.

Microfinance is seen as a vehicle or strategy to alleviating poverty through the provision of micro Credit and other financial services to low-income household and to other economically active individuals, or groups with the intention of helping them increase their income, operate viable business, reduce vulnerability to shocks and create jobs [6,7].

It is the intent of this paper to critically review the impact of microfinance banking institution and the growth of the Nigeria economy. Until now, all existing work both theoretical and empirical on microfinance banking institutions have dwelt on the concept of critical triangle of microfinance which is: financial sustainability, outreach and welfare impact. As they relate to poverty alleviation and financing the poor section of the nation's economy.

Most of the empirical microfinance research has been concentrated around the optimal design of the microfinance products, its impact on various development indicators, effects of moral hazards and adverse selection, eg. dealing with micro level. In contrast to the role of microfinance on macro level, this work will be looking at the role of microfinance on the macroeconomic level, particularly the year to year impact of microfinance economic variable channel through which the sector contributes to the financial intermediation and growth 
of the economy, instead of the use of aggregated variables to measure the effect of microfinance banking to the economy.

\section{Methodology}

Secondary data was collected for estimation from the central bank of Nigeria statistical bulletin various issues, the national policy framework for microfinance in Nigeria, world bank data for various years and issues, World Bank national accounts data, and OECD National Accounts data, CBN annual reports and statement of accounts for various years.

Thus, the data for the empirical study are the annual time series data ranging from 1992 to 2016. The data were converted from their absolute value to rate of changes data. The data consist of yearly data of the independent variables and dependent variables.

\section{Model Specifications}

\section{Time series regression model}

Let $Y_{t}$ be the dependent (exogenous) variable and $X_{1 t}, X_{2 t}, \ldots$, $\mathrm{X}_{\mathrm{kt}}$ be the independent variables.

A linear multiple regression model is given by:

$Y_{t}=\beta_{0}+\beta_{1} X_{1 t}+\beta_{2} X_{2 t}+\ldots+\beta_{k 1} X_{k 1 t}+U_{t}$

Where:

$\mathrm{Y}_{\mathrm{t}}$ - the dependent variable at time t proxies here areRGDP,

$\left(X_{1 t}, X_{2 t}, \ldots, X_{k}\right)$ - the independent variables at time $t$ proxied here by (MFBCG, MFBDG, MFBIG, MFBAG)

$$
\begin{array}{lll}
\mathrm{t} & - & \text { time. } \\
\mathrm{U}_{\mathrm{t}} & - & \text { stochastic term or error term. }
\end{array}
$$

Specifically, the model becomes
$R G D P=\beta_{0}+\beta_{1} M F B C G+\beta_{2} M F B D G+\beta_{3} M F B I G+\beta_{4} M F B A G+U_{t}$

Often, many econometric time series are better approximated by exponential trend, characterized with variance nonstationarity as well as non-normality [8-10], hence we need transformation most commonly logarithmic transformation to achieve linearity, normality and variance stationarity. Hence the model in equation 2 could be specified thus:

$\begin{aligned} \log \left(R G D P_{t}\right) & =\beta_{0}+\beta_{1} \log \left(M F B C G_{t}\right)+\beta_{2} \log \left(M F B D G_{t}\right)+\beta_{3} \log \left(M F B I G_{t}\right) \\ & +\beta_{4} \log \left(M F B A G_{t}\right)+U_{t}\end{aligned}$

Note, here we are not finding the logarithm of Equation 2 rather we are assuming that $Y_{t}$ and $X_{t}$ are trend stationary series which is exponential, and we have to log to linearize. Also, the introduction of $t$ is necessary to avoid a biased estimate of B's.

Test for cointegration will be conducted using Augmented Engle-Granger (AEG) Test and Hansen Parameter Instability test). The adjustment on the correlated error term will be handled using Cochran-Orcutt Regression method. Also, to guide against the effect of short-term disequilibrium of cointegrated variables we introduce the error correction model regression analysis. The model was first used by Sargan but was later popularized by Engle and Granger [8-10] and the popular theorem was known as Granger Representation theorem attached to this mechanism states that when two variables are cointegrated, the relationship between the two can be expressed as error correction mechanism model.

\section{Discussion and Results}

Tables 1-5 describes the Summary of the data collected for analysis, Unit Root Test, Augmented Dickey-Fuller Unit Root Test for Stationarity Descriptive statistics and Regression Analysis.

\begin{tabular}{|c|c|c|c|c|c|}
\hline YEAR & RGDP & MFBC & MFBD & MFBI & MFBA \\
\hline 1992 & 2.19 & 135.8 & 639.6 & 118.4 & 967.2 \\
\hline 1993 & 1.57 & 654.5 & $2,188.20$ & 326.6 & $3,198.60$ \\
\hline 1994 & 0.26 & $1,220.60$ & $3,216.70$ & 491.4 & $4,693.20$ \\
\hline 1995 & 1.87 & $1,129.80$ & $2,834.60$ & 354.3 & $4,106.50$ \\
\hline 1996 & 4.05 & $1,400.20$ & $2,876.30$ & 254 & $4,432.50$ \\
\hline 1997 & 2.89 & $1,618.80$ & $3,181.90$ & 384 & $4,706.40$ \\
\hline 1999 & 0.52 & $2,958.30$ & $4,140.30$ & 436.8 & $8,903.60$ \\
\hline 2000 & 5.52 & $3,666.60$ & $7,689.40$ & 450.2 & $12,014.70$ \\
\hline 2001 & 6.67 & $1,314.00$ & $3,294.00$ & 304.3 & $4,884.40$ \\
\hline 2002 & 14.6 & $4,310.90$ & $9,699.20$ & 925.5 & $15,463.50$ \\
\hline 2003 & 9.5 & $9,954.80$ & $18,075.00$ & $2,261.00$ & $28,689.20$ \\
\hline 2004 & 10.44 & $11,353.80$ & $21,407.90$ & $2,612.70$ & $34,162.30$ \\
\hline 2005 & 7.01 & $28,504.80$ & $47,523.70$ & $3,594.10$ & $82,866.90$ \\
\hline 2007 & 7.32 & $22,850.20$ & $4,127.70$ & $3,795.70$ & $75,549.80$ \\
\hline 2008 & 7.2 & $42,753.10$ & $61,568.10$ & $7,295.30$ & $122,753.80$ \\
\hline 2009 & 8.35 & $58,215.70$ & $76,662.00$ & $8,025.00$ & $151,610.00$ \\
\hline 2010 & 9.54 & $52,867.50$ & $75,739.60$ & $8,674.20$ & $170,338.90$ \\
\hline 2011 & 5.31 & $50,928.30$ & $59,375.90$ & $8,959.80$ & $117,872.10$ \\
\hline 2012 & 4.21 & $80,127.90$ & $98,789.10$ & $14,078.30$ & $189,293.40$ \\
\hline
\end{tabular}

Table 1. Summary of the data collected for analysis. 


\begin{tabular}{|c|c|c|c|c|c|}
\hline 2013 & 5.49 & $94,055.60$ & $121,787.60$ & $14,976.50$ & $237,837.60$ \\
\hline 2014 & 6.22 & $112,110.10$ & $110,688.40$ & $15,785.58$ & $221,652.30$ \\
\hline 2015 & 2.79 & $187,247.30$ & $159,453.50$ & $17,737.90$ & $343,883.10$ \\
\hline 2016 & -1.51 & $196,195.10$ & $149,798.40$ & $20,127.20$ & $326,223.10$ \\
\hline RGDP & $=$ & & \\
MFBC & Real Gross Domestic Product & & \\
MFBD & Microfinance Bank Credit & & \\
MFBA & Microfinance Bank Deposit & & \\
MFBA & Microfinance Bank Investment & & \\
\hline
\end{tabular}

Table 2. Modified Gordon growth measures model for the variables under consideration.

\begin{tabular}{|c|c|c|c|c|c|c|c|}
\hline \multicolumn{8}{|c|}{ Unit Root Test } \\
\hline $\begin{array}{c}\frac{Y 1_{t}-Y 1_{t-1}}{Y 1_{t-1}} \\
(\mathrm{RGDP})\end{array}$ & $\begin{array}{c}\frac{Y 2_{t}-Y 2_{t-1}}{Y 2_{t-1}} \\
(\mathrm{PCl})\end{array}$ & $\begin{array}{c}\frac{Y 3_{t}-Y 3_{t-1}}{Y 3_{t-1}} \\
(\mathrm{CPC})\end{array}$ & $\frac{X 1_{t}-X 1_{t-1}}{X 1_{t-1} \quad \text { (AGP) }}$ & $\begin{array}{c}X 1_{t}-X 1_{t-1} \\
X 1_{t-1} \\
(\mathrm{MFBCG})\end{array}$ & $\begin{array}{c}X 2_{t}-X 2_{t-1} \\
X 2_{t-1} \\
\text { (MFBDG) }\end{array}$ & $\begin{array}{c}X 3_{t}-X 3_{t-1} \\
X 3_{t-1} \\
(\text { MFBIG) }\end{array}$ & $\begin{array}{c}X 4_{t}-X 3_{t-1} \\
X 3_{t-1} \\
\text { (MFBAG) }\end{array}$ \\
\hline-0.2831 & 0.0445 & -0.0437 & 0.604 & 3.8196 & 2.4212 & 1.7584 & 2.3071 \\
\hline-0.8344 & 0.0292 & -0.0697 & 0.5078 & 0.8649 & 0.4700 & 0.5046 & 0.4673 \\
\hline 6.1923 & 0.0157 & 0.0359 & 0.7745 & -0.0744 & -0.1188 & -0.2790 & -0.1250 \\
\hline 1.1658 & 0.0663 & 0.1718 & 0.3548 & 0.2393 & 0.0147 & -0.2831 & 0.0794 \\
\hline-0.2864 & 0.0423 & -0.0584 & 0.1317 & 0.1561 & 0.1062 & 0.5118 & 0.0618 \\
\hline-0.1349 & 0.0344 & -0.0177 & 0.107 & 0.5609 & 0.3999 & -0.4313 & 0.3763 \\
\hline-0.7920 & 0.0158 & -0.0833 & 0.0641 & 0.1708 & -0.0705 & 1.0000 & 0.3746 \\
\hline 9.6154 & 0.072 & -0.0068 & 0.0571 & 0.2394 & 0.8572 & 0.0307 & 0.3494 \\
\hline 0.2083 & 0.0654 & 0.3793 & 0.3361 & -0.6416 & -0.5716 & -0.3241 & -0.5935 \\
\hline 1.1889 & 0.0563 & -0.0189 & 1.1095 & 2.2807 & 1.9445 & 2.0414 & 2.1659 \\
\hline-0.3493 & 0.1106 & 0.1247 & 0.0787 & 1.3092 & 0.8636 & 1.4430 & 0.8553 \\
\hline 0.0989 & 0.0879 & 0.0507 & 0.0762 & 0.1405 & 0.1844 & 0.1556 & 0.1908 \\
\hline-0.3285 & 0.0917 & 0.0642 & 0.2223 & 1.5106 & 1.2199 & 0.3756 & 1.4257 \\
\hline-0.0399 & 0.0866 & -0.2084 & 0.2455 & -0.4229 & -0.2842 & -0.2452 & -0.3345 \\
\hline 0.0877 & 0.0897 & 0.3407 & 0.1382 & 0.3891 & -0.8787 & 0.3992 & 0.3700 \\
\hline-0.0164 & 0.0719 & -0.2148 & 0.1811 & 0.8710 & 13.9158 & 0.9220 & 0.6248 \\
\hline 0.1597 & 0.0686 & 0.2826 & 0.151 & 0.3617 & 0.2452 & 0.1000 & 0.2351 \\
\hline 0.1425 & 0.0833 & -0.1136 & 0.1224 & -0.0919 & -0.0120 & 0.0809 & 0.1235 \\
\hline-0.4434 & 0.0419 & -0.0561 & 0.0758 & -0.0367 & -0.2161 & 0.0329 & -0.3080 \\
\hline-0.2072 & 0.0331 & -0.0264 & 0.1267 & 0.5733 & 0.6638 & 0.5713 & 0.6059 \\
\hline 0.3040 & 0.041 & 0.1787 & 0.0633 & 0.1738 & 0.2328 & 0.0638 & 0.2564 \\
\hline 0.1330 & 0.0497 & -0.0203 & 0.0715 & 0.1920 & -0.0911 & 0.0540 & -0.0681 \\
\hline-0.5514 & -0.5751 & -0.0125 & 0.0898 & 0.6702 & 0.4406 & 0.1237 & 0.5515 \\
\hline-1.5376 & 0.0025 & -0.044 & 0.0989 & 0.0478 & -0.0606 & 0.1347 & -0.0514 \\
\hline
\end{tabular}

Table 3. Augmented Dickey-Fuller Unit Root Test for Stationarity.

\begin{tabular}{|c|c|c|c|c|c|c|c|}
\hline Variable & State & ADF & P-value & Max Lag & AIC & D.W & Remark \\
\hline \multirow{2}{*}{$\log ($ RGDP) } & Level & -2.388 & 0.3757 & 0 & 2.5731 & 1.89 & Non- Stationary \\
\hline & First Difference & -5.881 & 0.0004 & 0 & 2.7769 & 1.96 & Stationary \\
\hline $\log (M F B C G)$ & Level & -4.7423 & 0.005 & 0 & 1.0102 & 1.75 & Stationary \\
\hline $\log (M F B D G)$ & Level & -5.1841 & 0.002 & 1 & 1.8696 & 2.02 & Stationary \\
\hline \multirow{2}{*}{$\log (M F B I G)$} & Level & -2.8896 & 0.188 & 6 & 0.6648 & 1.55 & Non-Stationary \\
\hline & First Difference & -5.2312 & 0.002 & 2 & 1.2874 & 2.13 & Stationary \\
\hline \multirow{2}{*}{$\log (M F B A G)$} & Level & -3.584 & 0.053 & 1 & 1.01 & 1.72 & Non-Stationary \\
\hline & First Difference & -6.4867 & 0.001 & 2 & 1.2689 & 2.31 & Stationary \\
\hline
\end{tabular}

\section{Discussion of findings}

Findings from unit root test: The result of the application Augmented Dickey-Fuller Unit Root Test for stationarity described to the variables (series) under study is show that Real Gross Domestic Product, Microfinance Bank Investment Growth and Microfinance Bank Asset Growth showed a unit root without significant deterministic trend coefficient at level. However, stationarity was observed after first difference for each of the variable mentioned. But
Microfinance Bank Credit Growth and Microfinance Bank Deposit Growth was found to be stationary at level, hence no differencing is needed. The test was conducted at different lag while the choice of appropriate model was made using the lag with minimum AIC and D.W that is approximately 2 which signifies uncorrelated error term for the test.

Findings from regression analysis: From the regression result on Table 4, the F-value of each of the models were not significant with a $(p>0.5)$ with the cointegrating and error 
Table 4. Descriptive statistics for the variables under study.

\begin{tabular}{|c|c|c|c|c|}
\hline Statistic & RGDP & MFBCG & MFBDG & MFBIG \\
\hline Mean & 5.25 & 39382.03 & 43329.16 & 5396 \\
\hline Median & 5.49 & 11353.8 & 18075 & 2612.7 \\
\hline Std. Deviation & 3.68 & 55943.27 & 50482.44 & 6407.52 \\
\hline skewness & 0.4 & 1.72 & 1.01 & 1.03 \\
\hline Kurtosis & 3.04 & 5.08 & 2.74 & 2.67 \\
\hline Minimum & -1.5 & 135.8 & 639.6 & 118.4 \\
\hline Maximum & 14.6 & 196195.1 & 159453.5 & 2.11 \\
\hline J. B. & 5.15 & 16.78 & 4.3 & 20127.2 \\
\hline Observation & 25 & 25 & 25 & 4.53 \\
\hline
\end{tabular}

Table 5. Regression Analysis of Log (RGDP) on Log (MFBCG), Log (MFBDG), Log (MFBIG) and Log (MFBAG).

\begin{tabular}{|c|c|c|c|}
\hline \multicolumn{4}{|c|}{ Regression Analysis } \\
\hline Variable & Cointegrating Regression Model & Error Correction Model (ECM) & Cochran-Orcutt Model \\
\hline \multirow{2}{*}{ Constant (C) } & $-8.2546^{* *}$ & 0.1286 & $-3.118^{* *}$ \\
\hline & -0.0298 & -0.5537 & -0.013 \\
\hline \multirow{2}{*}{$\log (M F B C G)$} & $-1.7776^{* *}$ & -1.2192 & -1.924 \\
\hline & -0.0431 & -0.0352 & -0.17 \\
\hline \multirow{2}{*}{$\log (M F B D G)$} & 0.3582 & 0.1614 & $0.1565^{\star \star}$ \\
\hline & -0.3975 & -0.0487 & -0.027 \\
\hline \multirow{2}{*}{$\log (\mathrm{MFBIG})$} & $-1.2109^{* *}$ & -1.0802 & $-0.7165^{\star *}$ \\
\hline & -0.0281 & -0.1665 & -0.029 \\
\hline \multirow{2}{*}{$\log (M F B A G)$} & $3.0694^{*}$ & 1.7306 & $2.7820^{* * *}$ \\
\hline & -0.0496 & -0.255 & -0.008 \\
\hline \multirow{2}{*}{$\hat{U}_{t-1}$} & \multirow{2}{*}{-} & 0.1286 & -0.0109 \\
\hline & & -0.5537 & -0.965 \\
\hline F-ratio & 3.5 & 2 & 6 \\
\hline \multirow{2}{*}{ Engle-Granger Statistic } & -3.2152 & \multirow{2}{*}{-} & \multirow{2}{*}{-} \\
\hline & -0.531 & & \\
\hline \multirow{2}{*}{ Hansen Statistic } & 0.4863 & \multirow{2}{*}{-} & \multirow{2}{*}{-} \\
\hline & $(>0.2)$ & & \\
\hline Number of Iteration & - & - & 3 \\
\hline D.W & 1.29 & 2.33 & 1.83 \\
\hline \multicolumn{2}{|c|}{ ( )- p-value, ${ }^{*}$-significant at $10 \%$. ${ }^{* *}$-significant at $5 \%,{ }^{* * *}$ - significant at $1 \%$, } & $W=$ Durbin-Watson Statistic. & \\
\hline
\end{tabular}

correction model but the Cochran-Orcutt model which result is displayed in column 3 of Table 4 found to be significant with the value of $(\mathrm{p}<0.05)$, for microfinance bank deposit growth and microfinance investment growth, while that of microfinance asset growth showed a significant $\mathrm{p}$ value at $1 \%$. while the coefficient of determination is highest $(0.78)$ for Cochran model and 0.60 for Cointegrating model and 0.19 for Error Correction model. The F- ratio of Cochran was also highest at 6.0 while the other models showed 3.5 and 2.0 respectively. Only microfinance bank credit growth reported a negative and no significant relationship. The significant $\mathrm{F}$ value and $\mathrm{R}^{2}$ indicate an overall adequacy of the regression model.

The Durbin-watson and F- stat are significant, hence the estimated equation can be relied upon in making inference concerning the influence of the growth variables on the economic growth.

\section{Conclusion}

With the findings of this research above, we therefore conclude that there exists a significant relationship between microfinance bank credit growth, microfinance bank deposit growth, microfinance bank investment growth, microfinance bank asset growth and economic growth. The probable reason why the relationship between micro finance bank credit and the real growth of the economy is negative is that either the credit is mismanaged or diverted to non-economic activities that don't impact the real economy. From experience we have known that most businesses in Nigeria are portfolio business existing only in the minds of the average businessman, when such business are given loans, they divert such funds to pleasure activities and not on real economic ventures that will grow the economy.

\section{Recommendation}

1 The Government agency (Central bank of Nigeria) in charge of the supervision of microfinance banks should put strict measures in place to ensure strict compliance to regulations so that credits advanced to customers are used for purely economic purpose for which they are granted.

2 The credit department of microfinance banks should be equipped to effectively monitor use of micro credit.

3 The investment department of microfinance banks 
should ensure credit lines are given to areas that will grow the economy, which are the real sectors of the economy like the manufacturing and agricultural sectors.

\section{Reference}

1. Akpan ES, Nneyi ID. Contribution of microfinance banks to the development of small and medium scale enterprises in Nigeria. Res J Fin Acc. 2015;6(8):2222-847.

2. Ademola AE, Arogundade K. The impact of microfinance on economic growth in Nigeria. J Emerg Trends Eco Managt. 2014;5(5):397-405.

3. Babagana SA. Impact assessment of the role of microfinance banks in promoting small and medium enterprise growth in Nigeria. J Eco Dev. 2010.

4. Microfinance policy regulatory and supervisory framework for Nigeria. Abuja: CBN. 2005.

5. EFInA (2010): Access to financial services in Nigeria
2010, Survey E-PPAN advisory committee on financial inclusion in Nigeria (2010): "Financial inclusion: Using card to capture the bottom of the pyramid in Nigeria". White paper from E-PPAN advisory committee on financial inclusion for Nigeria using payment cards.

6. Hulme D, Mosley P. Finance against poverty volume 1. London; New York: Routledge. 1996.

7. Hulme D. Impact assessment methodologies for microfinance: Theory, experience and better practice, World DeveLOP. 1991;28(1):2.

8. Wachukwu IP. Microfinance banking and the economic growth of Nigeria. (unpublished doctoral thesis). Rivers State University, Port Harcourt. 2018.

9. Yunus M, Alan J. The banker to the poor: Micro-lending and battle against world poverty. Pub Affairs. 1991;62:63.

10. Yunus M. Grameen Bank II: Lessons learn over a quarter of a century 2012.

\section{*Correspondence to:}

Wachukwu IP

Rivers State University

Port Harcourt

Nigeria

Tel: +234-8054783034

E-mail: pwachukwu@yahoo.com 